\title{
THE USE OF ORGANIC MANURES IN POLYCLTURE SYSTEM FOR TILAPIA, MULLET AND CARP
}

\section{El-Sayed H. El-Ebiary}

National Institute of Oceanography and FisheriesKayet Bay, Alexandria, Egypt

Key words: Organic manures, poLY Culture system, Tilapia mullet, Cavp

(Received may30, 1998)

\section{ABSTRACT}

The impact of organic manure ( poultry or cow manure) with or without 1 supplementary feeding on water quality, growth performance and production as well as survival rate of Oreochromis niloticus, Mugil cephalus and Cyprinus carpio reared in polyculture systems for 315 days growing period was investigated. The results demonstrated that :

1. Although, there were no nutrient limitations in experimental ponds, the nitrate and phosphate contents had higher levels in poultry manure treatment than cow manure ${ }^{\circ}$. Therefore, these ponds were rich in phyto and zooplankton.

2. Poultry manure ponds with supplementary feeding possessed the highest growth performance and production parameters as well as survival rate compared with those using supplementary feeding with or without cow manure .

\section{INTRODUCTION}

The scientific management aims to produce a low-cost fish, therefore the stress should be on the extent of utilization of natural food by inorganic or organic fertilizers on one hand, and better utilization of natural food through polyculture, on the other hand (Essa, et al. 1988 ). Much researches are needed to develop polycultur systems.

According to Huet ( 1970 ) and Annonymous (1972), the advantages of the use of organic fertilizers are : a) A shorter production cycle is 
possible than that obtained with inorganic fertilizers, especially forproduction of zooplankton in rearing ponds; b) Plant growth (natural fish food mainly phytoplankton) is increased through decomposition of organic materials and subsequent release of carbon dioxide; c) Organic fertilizers exert a favourable action on pond soil .

Utilization of organic and inorganic fertilizers in fish pond are most effective for vigorous development of the phytoplankton and zooplankton ( Rappaport et al., 1978; Schroeder, 1980; Woynarovich, 1980; Sharma and Olah, 1986; Essa, et al . 1988). A total gain of 7.6 tons /ha/240 days was achieved from a polyculture system which received a liquified cowshed manure ( Moav, et al, 1977), or 8.0 tons /ha/240 days in ponds received only duck dropping ( Wohlfarth, 1978 ). Miller ( 1976 ) noted that as natural food become over harvested due to intensive stocking, fish will accept supplementary feeding Essa, et al . (1989) and Hussein (1995) reported that, the highest growth of mullet, Mugil cephalus was recorded in polyculture condition with organic fertilizers and supplementary feeding.

The present study was undertaken to evaluate the effect of introducing organic fertilizers (poultry or cow manure) with or without supplementary feeding on chemical and biological characters of experimental pond water as well as growth performance and production in addition to feed utilization parameters of Nile tilapia, (Oreochromis niloticus); grey mullet, (Mugil cephalus) and common carp, (Cyprinus carpio) reared in polyculture conditions .

\section{MATERIAL AND METHODS}

Six earthen ponds ( $600 \mathrm{~m}^{2}$ each ) used in the present study are located at Alexandria Governorate Fish Farm, El-Nozha, Alexandria. The ponds have a sandy - clay bottom and average $1.00 \mathrm{~m}$ in depth. Polyculture of three fish species: Nile tilapia (Oreochromis niloticus); grey mullet (Mugil cephalus) and comm on carp (Cyprinus carpio) was done. Stocking density of fish was 5200 fish / feddan ( $65 \%$, O. niloticus; $30 \%$ $M$. cephalus and $5 \%$ C. carpio). The fish in the group A were given $150 \mathrm{~kg}$ of poultry manure per feddan at the beginning, then added $50-60 \mathrm{~kg} / \mathrm{feddan}$ bi-weekly; as well as fish were given pelleted supplementary feeds 
containing $18.0 \%$ crude protein (c.p) at the rate of $3 \%$ of fish body weight per day for six days a week. Composition and chemical analyses of the experimental supplementary diet are shown in table (1).

In group B, cow manure was used ( $150 \mathrm{~kg} / \mathrm{feddan}$ ) at the beginning, then added $50-60 \mathrm{~kg} /$ feddan bi-weekly, as well as fish were also fed pelleted supplementary feeds ( $18.0 \%$ C.P. ) . In group C, supplementary feeds were used only for feeding fish without fertilization treatment. Three treatments each replicated two times were assigned using a completely randomized experimental design .

During the experimental period ( 315 days), random fish samples from all experimental ponds, were collected monthly and weighed to adjust feed requirements and regulate growth performance.

Surface water temperatures were recorded daily at 10.00 am and $16.00 \mathrm{pm}$ with an ordinary thermometer. Dissolved oxygen, $\mathrm{pH}$, phosphate, nitrate and ammonia nitrogen were determined at weekly intervals by standard methods (Annonymous, 1985 ).

Estimation of the standing crops of both phytoplankton and zooplankton was performed bi-weekly in all experimental ponds through the experimental period ( 315 days ). Estimation of phytoplankton standing crop was carried out using sedimentation technique where one litre of water sample was collected and concentrated at $100 \mathrm{ml}$. Sub-samples were counted using a research microscope .

Results were expressed as the number of units / litre . Zooplankton samples were collected by filtering 50 litres of water ponds through $55 \mu$ plankton net, then concentrated samples were counted and results were expressed as organisms / litre .

Data were analyzed for statistical significance with one-way analysis of variance comparisons among means were made (Duncan, 1955; Snedecor and Cochran 1974). 


\section{Water quality}

\section{RESULTS AND DISCUSSION}

\section{a) Chemical observations :}

Studying the water quality of experimental ponds is of prime importance in regulating and following the suitability of their water for holding and rearing fish . For basic understanding of water quality in studied ponds, water temperature, dissolved oxygen, $\mathrm{pH}$, reactive phosphorus, nitrate and ammonia were determined and are given in Table (2). Water temperature in the experimental ponds groups (cow manure; poultry manure and supplementary feeding only) had similar values $\left(20.98^{\circ} \mathrm{C}-20.26^{\circ} \mathrm{C}\right)$ ). Nagel (1979) reported that, water temperature over $18{ }^{\circ} \mathrm{C}$ was best for warm water fish survival and growth and many species suffered and died below $12{ }^{\circ} \mathrm{C}$. The average values of dissolved oxygen in ponds with cow manure, poultry manure and supplementary feeding only were 5.72,5.36 and $5.60 \mathrm{~m} 1 / 1$, respectively . the lowest oxygen level was in the ponds with poultry manure in March, $(3.05 \mathrm{ml} / \mathrm{l})$. This is probably caused by continuous consumption of dissolved oxygen through organic matter oxidation .

Average values of dissolved oxygen $\left(\mathrm{DO}_{2}\right)$ in the experimental ponds seemed to be suitable for the three fish species. No much difference in $\mathrm{pH}$ values of water in the experimental pond groups (7.03, 7.45 and 7.68) was noticed . Hepher and Burginin (1981) showed that water pH from 6.5 -9.0 is quite reasonable for fish farming .

The nitrate $(N)$ and phosphate ( $P$ ) contents have higher values ( $\mathrm{N}: 0.214 \& \mathrm{P}: 0.172 \mathrm{mg} / \mathrm{l}$ ) in the ponds fertilized with poultry manure than the ponds fertilized with cow manure, (N: $0.053 \& \mathrm{P}: 0.169 \mathrm{mg} / \mathrm{I}$ ) and ( $\mathrm{N}: 0.021 \& \mathrm{P}: 0.164 \mathrm{mg} / \mathrm{l}$ ) in the non fertilized ponds. Burns and Stickney (1980) found increase in the levels of nitrate and phosphate with increasing the number of hens raised on fish ponds. Higher values of total ammonia were recorded in ponds fertilized with poultry manure $(0.214$ $\mathrm{mg} / \mathrm{l})$ than those of the ponds fertilized with cow manure $(0.053 \mathrm{mg} / \mathrm{l})$ and non fertilized ponds $(0.021 \mathrm{mg} / \mathrm{l})$. These values of ammonia in the experimental ponds are far below the toxic levels $(0.6-2.0 \mathrm{mg} / \mathrm{l})$ proposed by Essa et al.(19) for a short time exposure. 
b) Natural productivity:

The ponds fertilized by poultry and cow manure wre rich in phytoplankton, both in density and number of species, than the non fertilized ponds (table 3 ). The average standing crops during the experimental period were 1036,847 and $460 \times 10^{3} \mathrm{u} / \mathrm{l}$. respectively. The phytoplankton community in the pounds of the three groups was dominated with diatoms and green algae. The zooplankton population showed a clear difference between fertilized ponds with poultry or cow manure and unfertilized fish ponds, so it reached 1922,1828 and 947 ind./l respectively, the zooplankton population was mainly dominated by Rotifera forming 71.9, 53.0 and 80.4 $\%$ respectively of the total zooplankton community Table ( 3 ). Djajadiredja et al . (1980) reported that poultry manure is known to be the most powerful fertilizer for fish ponds, whereas sheep manure is usually regarded as less effective and cow manure is intermediate between them. Also Woynarovich ( 1976 ) reported that chicken and duck manures are excellent fertilizers compared to pig and goose manures. From the chemical and biological observation it can be concluded that, the water quality of the fertilized ponds was adequate for raising phyto-and zooplankton as the major natural fish food. Schroeder (1980) and Woynarovich (1980) noticed that ducks and poultry manures provide a nutrient base for dense blooms of phytoplankton, particularly nannoplankton which in turn triggers intense zooplankton development.

\section{2-Growth Performance and Survival Rate:}

Significant differences $(\mathrm{P}<0.05$ ) at the average of final weight, total and daily weight gain of fishes which werc reared together under the three types of polyculture were found ( table 4 ). These parameters were affected by the type of culture, because final body weights of fish species reared in group (A) which were fertilized with poultry manure and fed at supplenentary diet in ponds were improved compared with those reared in group (B) which were fertilized with cow manure and fed at supplementary diet in ponds and group (C) which were given supplementary feed (SF) only in the ponds . Specific growth rate ( SGR \%) and survival rate (\%) of fish reared in group (A) were not significantly different from fish reared in group ( B ), but showed significant differences $(P<0.05)$ compared with fish reared in group $(C)$ which received supplementary feed 
only . Woynarovich (1976) reported that chicken and duck manures are excellent fertilizers compared to pig and goose manures. Also, Li (1987) reported that poultry manure contains more energy than cow manure (chicken manure $1.05 \mathrm{MJ} / \mathrm{Kg}$ vs. Cow manure :0.42 MJ/Kg). Chakrabarti (1984) stated that using of poultry manure and inorganic fertilizer was found to be effective in increasing the production of plankton and bottom macro fauna. Nandeesha et al. (1984) in their study about the impact of poultry manure and silkworm fecal matter, either alone or in combination and also sewage on the production of fish food organisms for common carp cultured. They showed that poultry manure treatment resulted in highest numbers of phytoplankton and zooplankton.

Although the average daily gain of common carp was higher than those of tilapia and mullet respectively at the three groups of treatments (Ttable 4 ), yet the specific growth rate ( SGR \%) of mullet was the best compared with those of common carp and tilapia, This might be due to the initial weight of mullet $(0.7 \mathrm{~g})$ being less than those of tilapia and carp (6.7 $\& 6.8 \mathrm{~g}$ ), respectively. Also, Sarig (1981) observed that mass development of algae frequently appears in the fertilized ponds where supplementary food is added. He added that these algae are not fully utilized by common carp or tilapia, but serve as excellent food for Mugilidae . Essa et al . (1989) and Hussein (1995) reported that, the highest growth of mullet (M. cephalus) was recorded in polyculture conditions with organic fertilizers and supplementary feeding .

The increase in total body gain of common carp was higher than that of tilapia and mullet under the same treatment. This result was probably due to the few number of common carp fish in the ponds ( 260 fish / feddan ) compared with tilapia ( 3380 fish / feddan ) or mullet ( $1560 \mathrm{fish} / \mathrm{feddan}$ ) beside the differences in the natural feeding habitats among different fishes in the experimental ponds. These observations may be attributed to that the fish at low density consume maximum amount of food available and grow faster. Huet (1970) concluded that carp is the most productive fish compared with tilapia or mullet, in addition, carp is more efficient to feed on artificial or supplementary feeding than mullet or tilapia .

Higher survival rate of tilapia at all treatments compared to those of common carp and mullet was observed during the present study. This may 
be due to : that tilipia is more tolerant to many conditions (Bard et al., 1976; and Liao \& Chang,1983). Also mullet is a sensitive fish to handling and low oxygen concentration (El-Ebiary, 1982 \& Salama 1994)

The results showed also that, the best feed conversion ratio was at group $\mathrm{A}(3.0)$, while for group B \& $\mathrm{C}$ were $3.2 \& 3.4$ respectively. Rappaport and Sarig (1987) reported that addition of chicken manure under intensive fish culture reduce food conversion ratio by 0.4 units . Woynarovich (1980) reported, a food conversion ratio of 1.8-2.2 for fish reared in ponds with ducks. In contrast, Edwards et al. (1994) found that ruminant manure (buffalo manure) was shown to be a poor pond fertilizer because of its low nutrient content and adverse effect on water quality .

\section{Fish Production :}

Table ( 5 ) presents total fish yield per feddan for fish reared in the three farming systems. Fish received supplementary feeding and poultry manure give a higher overall yield $(909.7 \mathrm{~kg} / \mathrm{fed}$.) than those received supplementary feeding and cow manure $(674.8 \mathrm{~kg} / \mathrm{fed})$ or fish given supplementary feed only ( $467.2 \mathrm{~kg} / \mathrm{fed}$.) Increased production of fish in poultry and livestock integrated farm is predictable since waste feed and excreta fertilize the ponds (Djajadiredja et al ., 1980). A total gain of 7.6 tons/ ha/240 days was achieved from a polyculture system which received a liquified cowshed manure (Moav et al, 1977). In contrast, 8.0 tons $/ \mathrm{ha} / 240$ days in ponds received only poultry dropping (Wohlfarth, 1978). Miller (1976) noted that as natural food become over-harvested due to intensive stocking, fish will accept supplementary feeding .

\section{Conclusion}

From the previous results it is interesting to conclude that :

The effect of organic fertilizers (poultry and cow manure) increased significantly the productivity of phyto and zooplankton in fish ponds . 
There were significant differences in the final average body weight of fish species reared under the three types of culture. Body weight of fish species was improved in poultry fertilized ponds using supplementary feeding than the other two groups .

Fish yield / feddan obtained from ponds fertilized with poultry manure was significantly higher than those obtained from the other two treatments.

The three species (Orechromis niloticus, Mugil cephalus and Cyprinus carpio ) did not affect the growth and production of each other when reared together in polyculture ponds.

\section{ACKNOWIEDGEMENTS}

The author wishes to express his hearty thanks to Dr. M.A. Essa, Head of Fish Farm Project, Alexandria Governorate for the facilities offered throughout this work and revsion of the manuscript .

\section{REFERENCES}

Annon ( 1972 ). Contribution a l'étude de l'utilisation de la fumure organique en pisciculture tropical. Annexe No. 6 au rapport final du C.T.F.T. pour FAO project .

Annon ( 1985 ). Standard methods for the examination of water and waste water, $16^{\text {th }}$ edition, APHA, Washington, D.C. 1268 pp.

Bard, J.; Dekimp, P. and Lazard, J. ( 1976 ). Handbook of fish cuiture.Centre Technique Forestior Tropical, Nogent - Sur- Marne, France, $165 \mathrm{pp}$.

Burns, R.P., and Stickney, R.R. ( 1980 ) . Growth of Tilapia aurea in ponds receiving poultry wastes. Aquaculture, 20: 117-121 .

Chakrabarti, N.M. (1984). Effect of organic manure and inorganic fertilizers on productivity of brackish water ish pond. Environ. Ecol., .2(4), 271 - 277 . 
Djajadiredja, Z.; Jangkaru, R. and Junus, M. (1980). AgricultureAquaculture Integrated Farming Systems in West Java. Indonesia ICLARM Conference Proceeding, $4: 143-165$.

Duncan, D.B. ( 1955 ). Multiple F-test. Biometrics, 11:1-42. Edwards, P.;

El-Ebiary, E.H. ( 1982 ). Studies on Fish Culture. Observation on the survivalor mortality in mullet fry. M. Sc. Thesis, Fac. Agric., Alex., Univ., Egypt.

Essa, M.A; El-Sherif, Z.M.; Abdel Moati, A.R. and Aboul- Ezz, S. M.

(1988). An experiment for Scientific management of El-Khashaa Fish farm ( Kafr El-Shiekh Governorate ). Proc. I $^{\text {st }}$ Sc. Com. Develop. Fish. Resour. Fac. Agr. Alex.

Essa, M.A; El-Sherif, Z.M.; Abu El-Ezz, S.A. and Abd El-Moati, A.R.

( 1989 ). Effect of water quality, food and viability and crowding onrearing conditions and growth parameter of some economical fish speciesgrown under polyculture systems. Bull. Nat. Inst. Ocean. \& Fish . ARE, $15(1): 125-134$.

Hepher, B. and Pruginin, Y., (1981). Commercial fish farming with special reference to fish farming culture in Israel . A. WileyInterscience Publication, John Wiley and Sons, New York.

Hussein, M.S. ( 1995 ) Semi-intensive fish culture in some Egyptian fish farms. ph. D. Thesis. Fac. Agr. Suez Canal Univ, 256 pp.

Huet, M. ( 1970 ) . Text Book of fish culture- breeding and cultivation of fish. Londone, Fishing News (Books) L.T.D., 436 pp.

Li, D.W. ( 1987 ). Integrated fish farming and vegetable growing - Malayan Agric. J. 35(3): $156-166$.

Liao, C. and Chang S. ( 1983 ). Studies on the feasibility of red tilapia culture in saline waters. Proc. Interno. Symp. On Tilapia in Aquac. Tel Aviv. Univ. Israel. $524-533$. 
Miller, J.W. (1976). Fertilization and feeding practices in warm- water pond fish culture in Africa. In Symposium on Aquaculture in Africa, Accra, Ghana. CIFA Tech. Pap., (4) suppl. 1,791 pp.

Moav, R.; Wohlfarth, G. Schroeder, G.L.; Hulata, G. and Bara, H. ( 1977 ). Intensive polyculture of fish in fresh-water ponds. I substitution of expensive feeds by liquid cow manure. Aquac. 10:25 - 43 .

Nagel, L. ( 1979 ). Aquaculture in the third world. J. of Anim. Res. And develop., 9, $77 \mathrm{pp}$.

Nandeesha, M.C. ; Keshavanath, p. and Dinesh, K.R. ( 1984 ) Effect of three organic manures on plankton production in fish ponds. Environ.Ecol., $2(4) ; 311-318$

Pacharaprakiti, C. and Yomjinda, M. ( 1994 ). An assessment of the role of buffalo manure for pond culture of tilapia. q Auaculture126:8395.

Rappaport, U. and Sarig, S. ( 1987). .The results of manuring on intensive growth fish farming at the Ginosar Station Ponds Bamidgeh, 30 (2); $27-36$.

Rappaport, U.; Sarig, S. and Bejerano, Y. ( 1978). . Observations on the use of organic fertilizers in intensive fish farming at the Ginosar station. Bamidgeh, $29(2): 57-70$.

Salama, M.E. ( 1994 ) . Mixed culture of Mullet, Nile tilapia, carp and silver carp under different management regimes. Delta J. of Sci., 18(3): 191-209

Sarig, S. ( 1981 ) The Mugilidae in polyculture in fresh and brackish water fishponds. 391 - 393 in Aquacuiture of grey mullets. Edited by O.H. Oren, Israel Ocean. And Limmol. Res., 507 pp.

Schroeder, G.L. ( 1980 ). Fish farming manure loaded ponds. R.S.V. pollin \& Z. H. Shehadeh, ( eds ), Integrated Agriculture - Aquaculture farming systems. ICLARM Conference proceedings., $4: 73-86$. 
Sharma, B.K and Olah, J. ( 1986 ). Integrated fish-pig farming in India and Hungary. Aquaculture, $54: 135-139$.

Snedecor, G.W. and Cochran, W.G. ( 1974 ) . Statistical Methods . Iowa State Univ. Press, Ames. IA. 341 pp.

Wohlfarth, G. (1978). Utilization of the manure in fish farming . In : Pastakia, C.M.R. (eds ), Proc. Of the Conf. On Fish Farming and Wastes, Inst. Of fisheries and society of chemical Industry, London, pp. $78-95$

Woynarovich, E. ( 1976). The feasibility of combining animal husbandry with fish farming, with special reference to duck and pig production, In Pillay, T.V.R. \& Dill, W.A. (eds.) . Advances in aquaculture; 203 208.

Woynarovich, E. ( 1980 ). Raising ducks on fish ponds. Integrated Agriclture - Aquaculture farming systems. Iclarm Conf. Proc. 4, 129 134 Philippines. 
Table(I) Composition and proximate analyses of supplementary fish diet

\begin{tabular}{|l|l|}
\hline Ingredient & $\%$ \\
\hline Broken wheat & 10.0 \\
Wheat milling by - product & 25.0 \\
Bread crumps & 50.0 \\
Blood meal & 9.8 \\
Fish meal & 5.0 \\
Vitamins \& mineral mix & 0.2 \\
& \\
Proximate analysis & \\
Moisture & 8.53 \\
Crude protein & 18.06 \\
Crude lipid & 1.44 \\
Crude fiber & 1.70 \\
Ash & 2.65 \\
Nitrogen free extract & 67.62 \\
\hline
\end{tabular}


The Use Or Organic Manures In Polyculture System For Tilapia, Mullet And Carp 145

Table (2) Average water quality criteria of experimental ponds

\begin{tabular}{|l|l|l|l|}
\hline Treatmets & PM+SF & CM + SF & SF \\
\hline Water temp. ?C & $20.84 \pm 1.35$ & $20.98 \pm 1.33$ & $20.26 \pm 1.40$ \\
Dissolved $\mathrm{O}_{2}(\mathrm{mg} / \mathrm{l})$ & $05.36 \pm 0.25$ & $05.72 \pm 0.17$ & $05.60 \pm 0.21$ \\
$\mathrm{pH}$ & $07.45 \pm 0.03$ & $07.03 \pm 0.03$ & $07.68 \pm 0.04$ \\
Phosphate $(\mathrm{mg} / \mathrm{l})$ & $0.172 \pm 0.02$ & $0.169 \pm 0.04$ & $0.164 \pm 0.05$ \\
Nitrate (mg/) & $0.214 \pm 0.05$ & $0.053 \pm 0.02$ & $0.021 \pm 0.01$ \\
Ammonia $(\mathrm{mg} / \mathrm{l})$ & $0.246 \pm 0.05$ & $0.134 \pm 0.06$ & $0.115 \pm 0.03$ \\
\hline
\end{tabular}

$P M \quad$ : Poultry manure

$C M$ : Cow manure

SF : Supplementary feeding

Table (3) Average phytopl( $u / l)$ and zooplankton (ind. $\Omega$ ) in experimental ponds

\begin{tabular}{|l|l|l|l|}
\hline Treatmet & $\boldsymbol{P M}+\boldsymbol{S F}$ & $\boldsymbol{C M}+\boldsymbol{S F}$, & $\boldsymbol{S F}$ \\
\hline Zooplankton & & & \\
\hline (ind./litre) & & & \\
Rotifera & 1382 & 968 & 761 \\
Copepoda & 379 & 769 & 148 \\
Cladocera & 139 & 75 & 28 \\
Others & 22 & 16 & 10 \\
Total & 1922 & 1828 & 947 \\
Phytoplankton & 1036 & 847 & 460 \\
\hline (1000 u /litre) & & & \\
\hline
\end{tabular}

$P M \quad$ : Poultry manure

$C M$ : Cow manure

SF : Supplementary feeding

rable (4) Growth performance and survial rate (\%) of 0 . niloticus, $M$. cepltalus and $C$. carpio reared together in polyculture at different manuring and feeding in earthen ponds for 315 days 


\begin{tabular}{|c|c|c|c|c|c|c|c|}
\hline \multirow{2}{*}{ Treatonent } & \multirow{2}{*}{ Species } & \multicolumn{2}{|c|}{$\begin{array}{l}\text { Live weight } \\
\text { / Fish (z) }\end{array}$} & \multicolumn{2}{|c|}{$\begin{array}{l}\text { Gain /fish } \\
(x)\end{array}$} & \multirow{2}{*}{$\begin{array}{l}\text { SGR* } \\
(\%)\end{array}$} & \multirow{2}{*}{1} \\
\hline & & Initial & Final & Total & $(2)^{/ / d a y}$ & & \\
\hline $\begin{array}{l}\text { Poultry manure } \\
\text { Supplementary }\end{array}$ & $\begin{array}{l}\text { O. } \\
\text { niloticus: } \\
M . \\
\text { cephalws } \\
\text { C. carpio }\end{array}$ & $\begin{array}{l}6.7 \\
0.7 \\
6.8\end{array}$ & $\begin{array}{l}181.41 \\
175.23 \\
987.60\end{array}$ & $\begin{array}{l}174.71 \\
174.53 \\
980.80\end{array}$ & $\begin{array}{l}0.55 \\
0.55 \\
3.11\end{array}$ & $\begin{array}{l}1.05 \\
1.75 \\
1.58\end{array}$ & $\begin{array}{l}86.3 \\
74.5 \\
78.9\end{array}$ \\
\hline $\begin{array}{l}\text { Supplementary } \\
\text { feeding }\end{array}$ & Mean & 4.73 & $448.08^{\mathrm{X}}$ & $443.35^{x}$ & $1.40^{\mathrm{A}}$ & $1.46^{\lambda}$ & $79.9^{K}$ \\
\hline $\begin{array}{l}\text { Cow manure } \\
+ \\
\text { Supplementary } \\
\text { foeding }\end{array}$ & $\begin{array}{l}\text { O. } \\
\text { niloticus } \\
M . \\
\text { cephalus } \\
\text { C. carpio }\end{array}$ & $\begin{array}{l}6.7 \\
0.7 \\
6.8\end{array}$ & $\begin{array}{l}133.76 \\
154.03 \\
700.48\end{array}$ & $\begin{array}{l}126.97 \\
153.33 \\
693.68\end{array}$ & $\begin{array}{l}0.40 \\
0.49 \\
2.20\end{array}$ & $\begin{array}{l}0.95 \\
1.71 \\
1.47\end{array}$ & $\begin{array}{l}84.9 \\
73.8 \\
76.5\end{array}$ \\
\hline $\begin{array}{l}\text { Supplementary } \\
\text { feeding }\end{array}$ & Mean & 4.73 & $329.39^{\mathrm{B}}$ & $324.66^{8}$ & $1.03^{B}$ & $1.38^{x}$ & $78.4^{\Lambda}$ \\
\hline \multirow{2}{*}{$\begin{array}{l}\text { Supplementary } \\
\text { feeding }\end{array}$} & $\begin{array}{l}\text { O. } \\
\text { niloticus } \\
M . \\
\text { cephalus } \\
\text { C. carpio }\end{array}$ & $\begin{array}{l}6.7 \\
0.7 \\
6.8\end{array}$ & $\begin{array}{l}109.53 \\
102.50 \\
477.72\end{array}$ & \begin{tabular}{|l|}
102.83 \\
101.80 \\
470.92
\end{tabular} & $\begin{array}{l}0.33 \\
0.32 \\
1.49\end{array}$ & $\begin{array}{l}0.89 \\
1.58 \\
1.35\end{array}$ & $\begin{array}{l}79.1 \\
66.8 \\
75.0\end{array}$ \\
\hline & Mean & 4.73 & $229.92^{C}$ & $225.18^{\mathrm{C}}$ & $0.71^{2}$ & $1.27^{8}$ & $73.6^{8}$ \\
\hline $\begin{array}{l}\text { Grand Mean } \\
\pm \text { SE }\end{array}$ & & $\begin{array}{l}4.73 \\
0.00\end{array}$ & $\begin{array}{l}335.80 \\
63.05\end{array}$ & $\begin{array}{l}331.07 \\
63.05\end{array}$ & $\begin{array}{l}1.05 \\
0.20\end{array}$ & $\begin{array}{l}1.37 \\
0.06\end{array}$ & \begin{tabular}{|l|}
71.3 \\
1.9 \\
\end{tabular} \\
\hline
\end{tabular}

- SGR, specific growth rate $\%=100$ ( $\mathrm{Ln}$ final weight $-\mathrm{L} \mathrm{n}$ initial weight $)$ I days

- Mean in the same columnhaving different superscript are significantly different

$$
(\mathrm{P}<0.05)
$$




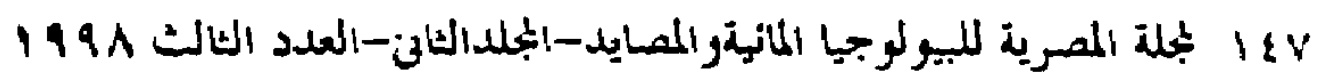

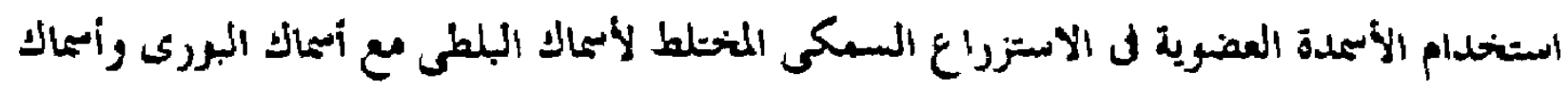
المبروك

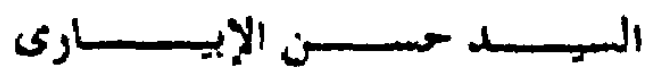

المعهد المقومى لعلوم البحار والمهايد الإسكندرية المدية

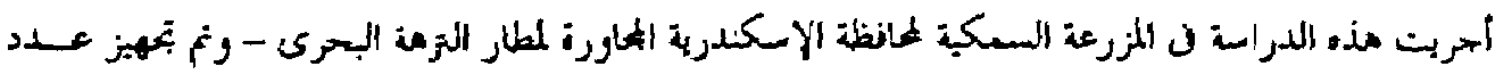

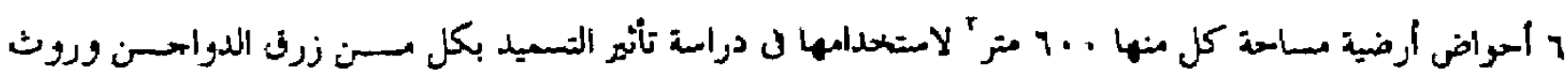

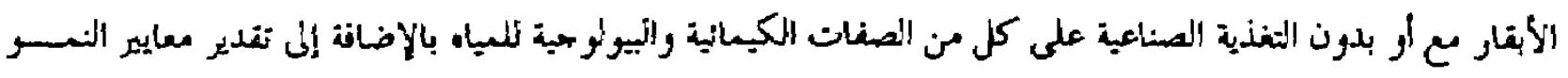

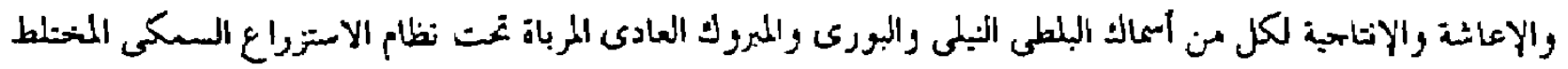

وقد أظهرت نتانج الدراسة أن :

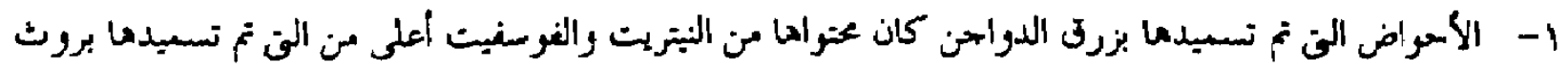

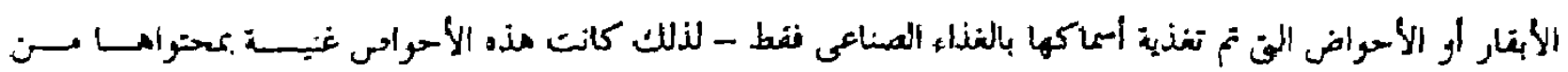

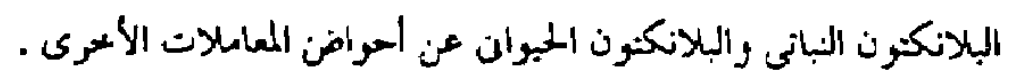

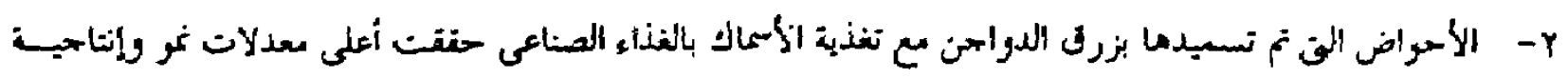

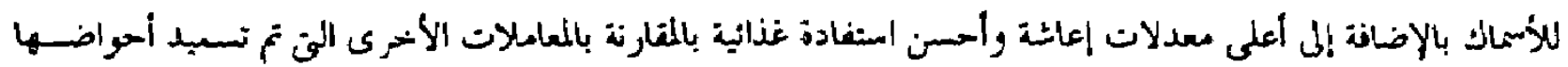

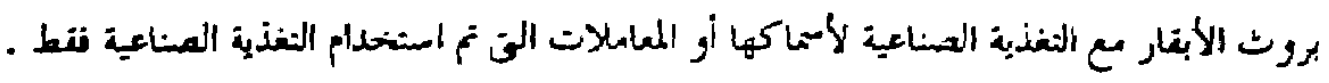

